\title{
Metoprolol Fumarate
}

National Cancer Institute

\section{Source}

National Cancer Institute. Metoprolol Fumarate. NCI Thesaurus. Code C66133.

The fumarate salt form of metoprolol, a cardioselective competitive beta-1 adrenergic receptor antagonist with antihypertensive properties and devoid of intrinsic sympathomimetic activity. Metoprolol antagonizes beta 1-adrenergic receptors in the myocardium, thereby reducing the rate and force of myocardial contraction, and consequently a diminished cardiac output. This agent may also reduce the secretion of renin with subsequent reduction in levels of angiotensin II thereby preventing vasoconstriction and aldosterone secretion. 